\title{
JUURNAL_RU
}

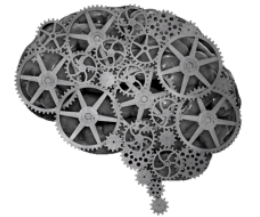

COMPANY GROUP "INTELLEKT"

\author{
Бачурина О.И. \\ ГБУ РО РОКБ \\ Ростов-на-Дону, Россия
}

doi: 10.18411/1j2016-5-2-01

\section{Стабилизация слуховой функции при болезни Меньера}

На сегодняшний день существует множество определений производительных сил. Начиная от самых простых, понятных всем и заканчивая самыми сложными, глубоко научными определениями.

Болезнь Меньера характеризуется периодически возникающими приступами системного головокружения, наличием шума в ухе и прогрессирующим снижением слуха [1]. Степень выраженности слуховых и вестибулярных нарушений с годами приобретает различную направленность: если вестибулярные нарушения постепенно ослабевают, то слуховые расстройства часто заканчиваются развитием стойкой тугоухости и даже глухоты $[2,3]$. В связи с этим стабилизация слуховой функции как один из моментов социальной реабилитации больного должна быть предметом особого внимания врача.

Для успешного лечения слуховых расстройств при болезни Меньера необходим точный диагноз, поскольку подобное сочетание слуховых и вестибулярных нарушения встречается и при другой патологии внутреннего уха $[4,5,6]$. Главными причинами нарушения слуховой функции при болезни Меньера являются биохимические и гидродинамические изменения во внутреннем ухе. 
В комплексе средств медикаментозного лечения кохлеовестибулярных нарушений важное место отводится вазоактивным препаратам. Эти препараты должны отвечать ряду требований, главное из которых - воздействие на церебральную гемодинамику, что обеспечивает улучшение кровообращения области вестибулярных ядер. Однако для лечения болезни Меньера необходимо улучшение кровоснабжения как ядерного, так и периферического отделов слухового и вестибулярного анализаторов.

К сожалению, далеко не все вазоактивные препараты центрального действия способны оптимизировать кровообращение внутреннего уха. Одним из немногих средств, которым присуще это свойство, является бетагистина дигидрохлорид. Фармакологические исследования на животных выявили увеличение кохлеарного кровотока при введении бетагистина дигидрохлорида. Этот эффект зависит от дозы препарата и в большей степени проявляется в сосудистой сети улитки, чем в системном сосудистом русле.

Механизм действия бетагистина дигидрохлорида (бетасерка) включает действие на кохлеарный кровоток, на центральные и рецепторные отделы вестибулярного анализатора.

Действие бетагистина реализуется, в основном, через гистаминовые рецепторы, значительное количество которых обнаружено и в мелких артериях внутреннего уха. Последний факт объясняет эффект улучшения кровоснабжения внутреннего уха под влиянием бетагистина дигидрохлорида.

Целью нашего исследования было изучение влияния бетасерка (бетагистина дигидрохлорида) на слуховую функцию у больных с болезнью Меньера.

Бетасерк был использован для курсового лечения 14 больных в возрасте от 28 до 44 лет, 11 женщин и 3 мужчин. Продолжительность заболевания составляла в среднем 2,7 года. Все больные жаловались на одностороннюю флюктуирующую тугоухость и шум в ухе, усиливающийся накануне и во время 
приступа головокружения. Типичные приступы системного головокружения наблюдались от 2 до 8 раз в год.

Больным проведено общеклиническое и отоневрологическое исследование, произведена тональная пороговая аудиометрия и триплексное сканирование сосудов шеи.

По данным аудиометрии у всех больных отмечено повышение порогов слуха по воздушной проводимости в зоне речевых частот от 20 до 50 дБ. Преобладающим типом кривых был вогнутый, с наличием костно-воздушного интервала от 10 до 30 дБ на низких частотах.

Больным проведено лечение бетасерком в дозах, рекомендуемых фирмой производителем: по 16 мг 3 раза в день. Продолжительность лечения составила 3 месяца. Результаты лечения оценивали по окончанию приема препарата и по истечению срока от 8 до16 месяцев.

Субъективное улучшение отмечено не ранее чем через 3 недели от начала приема препарата. Стабилизация вестибулярной функции достигнута у всех больных - повторения приступов головокружения в указанные сроки наблюдения не отмечено.

Аудиогические нарушения регрессировали у 9 больных, при аудиометрическом исследовании которых выявлено понижение порогов слуха по воздушной проводимости на 15 - 30 дБ по сравнению с исходными значениями, по костной - на 10 - 20 дБ. 3 больных отметили ослабление или исчезновения субъективного ушного шума.

При исследовании мозгового кровообращения отмечено увеличение кровенаполнения в сосудах вертебробазилярного бассейна по сравнению с исходными данными.

Таким образом, у большинства больных, принимавших бетасерк, зарегистрировано улучшение слуховой функции. Важным прогностическим моментом является развитие у этих больных стойкой вестибулярной компенсации, поскольку на состояние слухового рельефа оказывает влияние 
частота и выраженность приступов головокружения: с нарастанием их частоты и продолжительности нарушения слуха прогрессируют.

Наши наблюдения свидетельствуют о высокой эффективности бетасерка в лечении болезни Меньера, что согласуется с данными других авторов. В результате курсового применения препарата не только достигнута вестибулярная ремиссия, но и отмечено стойкое улучшение слуховой функции у 64\% больных.

\section{Литература:}

1. Бойко Н.В. Головокружение в практике врача-терапевта. Лечащий врач. 2010. № 4. C. 86 .

2. Бойко Н.В., Колмакова Т.С. Содержание гормонов в крови при болезни Меньера. Рос. оторинолар. 2014. Т. 72. № 5. С. 15-19.

3. Boyko N.V., Kolmakova T.S. Blood hormones level in patients with Menieres disease. Мат III Междунар науч-практ конф «Современные проблемы развития фундаментальных и прикладных наук» Praha, Czech Republic. 2016. T. 1. C. 16-19.

4. Бойко Н.В. Синдром расширенного водопровода преддверия. Российская оториноларингология. 2015. Т. 78. № 5. С.79-82

5. Бойко Н.В., Колесников В.Н. Фистула лабиринта у больных хроническим гнойным средним отитом. Российская оториноларингология. 2012. № 4. C. $127-132$.

6. Колесников В.Н., Бойко Н.В. Хирургическое лечение хронического гнойного среднего отита, осложненного фистулой лабиринта. Российская оториноларингология. 2012. Т. 61. № 6. С. 75-80 